University of Nebraska - Lincoln

DigitalCommons@University of Nebraska - Lincoln

Faculty Publications in the Biological Sciences

Papers in the Biological Sciences

2013

\title{
Nitrogen uptake strategies of edaphically specialized Bornean tree species
}

\author{
Sabrina E. Russo \\ University of Nebraska - Lincoln, srusso2@unl.edu \\ Amy Kochsiek \\ University of Nebraska - Lincoln \\ Jocelyn Olney \\ University of Nebraska - Lincoln \\ Lauren Thompson \\ University of Nebraska - Lincoln \\ Amy E. Miller \\ U.S. National Park Service
}

See next page for additional authors

Follow this and additional works at: https://digitalcommons.unl.edu/bioscifacpub

Part of the Biology Commons

Russo, Sabrina E.; Kochsiek, Amy; Olney, Jocelyn; Thompson, Lauren; Miller, Amy E.; and Tan, Sylvester, "Nitrogen uptake strategies of edaphically specialized Bornean tree species" (2013). Faculty Publications in the Biological Sciences. 765.

https://digitalcommons.unl.edu/bioscifacpub/765

This Article is brought to you for free and open access by the Papers in the Biological Sciences at DigitalCommons@University of Nebraska - Lincoln. It has been accepted for inclusion in Faculty Publications in the Biological Sciences by an authorized administrator of DigitalCommons@University of Nebraska - Lincoln. 


\section{Authors}

Sabrina E. Russo, Amy Kochsiek, Jocelyn Olney, Lauren Thompson, Amy E. Miller, and Sylvester Tan 


\title{
Nitrogen uptake strategies of edaphically specialized Bornean tree species
}

\author{
Sabrina E. Russo • Amy Kochsiek • \\ Jocelyn Olney $\cdot$ Lauren Thompson • \\ Amy E. Miller · Sylvester Tan
}

Received: 13 August 2013/Accepted: 19 September 2013/Published online: 25 September 2013

(C) Springer Science+Business Media Dordrecht 2013

This document is a U.S. government work and is not subject to copyright in the United States.

\begin{abstract}
The association of tree species with particular soil types contributes to high $\beta$ diversity in forests, but the mechanisms producing such distributions are still debated. Soil nitrogen $(\mathrm{N})$ often limits growth and occurs in differentially available chemical forms. In a Bornean forest where tree species composition changes dramatically along a soil gradient varying in supplies of different $\mathrm{N}$-forms, we investigated whether tree species' $\mathrm{N}$-uptake and soil specialization strategies covaried. We analyzed foliar ${ }^{15} \mathrm{~N}$ natural abundance for a total of 216 tree species on clay or sandy loam (the soils at the gradient's extremes) and conducted a ${ }^{15} \mathrm{~N}$-tracer experiment with nine specialist and generalist species to test whether species displayed flexible or differential uptake of ammonium and nitrate. Despite variation in ammonium and nitrate supplies and nearly $4 \%$ difference in foliar $\delta^{15} \mathrm{~N}$ between most soil specialists and populations of generalists on these soils, our ${ }^{15} \mathrm{~N}$
\end{abstract}

S. E. Russo $(\varangle) \cdot$ A. Kochsiek · J. Olney · L. Thompson School of Biological Sciences, Manter Hall, University of Nebraska, Lincoln, NE 68588-0118, USA

e-mail: srusso2@unl.edu

S. E. Russo - S. Tan

Center for Tropical Forest Science, Arnold Arboretum Asia Program, Harvard University, Cambridge, MA 02138, USA

\section{A. E. Miller}

Southwest Alaska Network, U.S. National Park Service, Anchorage, AK 99501, USA tracer experiment showed little support for the hypothesis that soil specialists vary in $\mathrm{N}$-form use or the ratios in which they use these forms. Instead, our results indicate that these species possess flexible capacities to take up different inorganic $\mathrm{N}$ forms. Variation between soil specialists in uptake of different $\mathrm{N}$ forms is thus unlikely to cause the soil associations of tree species and high $\beta$ diversity characteristic of this Bornean rain forest. Flexible uptake strategies would facilitate $\mathrm{N}$-acquisition when supply rates of $\mathrm{N}$-forms exhibit spatiotemporal variation and suggest that these species may be functionally redundant in their responses to $\mathrm{N}$ gradients and influences on ecosystem $\mathrm{N}$-cycles.

Keywords Ammonium · 15-N · Malaysia . Nitrate $\cdot$ Soil gradient $\cdot$ Stable isotope tracer experiment $\cdot$ Tropical forest

\section{Introduction}

$\beta$ diversity, or the diversity contributed by turnover of species along environmental gradients, arises in forests because many tree species occur only in particular habitats, defined by the availability of above and belowground resources and interactions with herbivores and pathogens (Whittaker 1956; Ashton 1964; Janzen 1974; Whitmore 1978). Although much 
research has demonstrated how light availability affects tree species' distributions (e.g., Chazdon 1986; Kobe et al. 1995; Dalling and Hubbell 2002), the mechanisms contributing to tree species' specialization to particular soil habitats are still debated. Most hypothesized mechanisms involve species' differential requirements for and responses to variation in soil nutrient or water availability (Grime 1979; Tilman 1982; Chapin et al. 1986, 1993).

Nitrogen $(\mathrm{N})$ often limits or co-limits plant growth, and is critical to photosynthetic carbon gain (Field and Mooney 1990; Marschner 1995). Soil N occurs in a variety of organic and inorganic forms that are differentially available to plant roots (Marschner 1995). Complex organic $\mathrm{N}$ in litter is mineralized by microorganisms, producing ammonium $\left(\mathrm{NH}_{4}^{+}\right)$that is converted to nitrate $\left(\mathrm{NO}_{3}^{-}\right)$. Plants are often flexible in their capacity to take up the chemical forms of $\mathrm{N}$ that are the most readily available (Scott and Rothstein 2011), but some species also display preferences for particular forms of $\mathrm{N}$ (von Wirén et al. 1997). It is still unclear how prevalent generalized versus specialized $\mathrm{N}$-uptake strategies are among plant species and to what extent strategies vary among ecosystems, soil environments, and plant functional groups.

Competition in the rhizosphere for different forms of $\mathrm{N}$ can affect the partitioning of soil $\mathrm{N}$ among plant species and is thus expected to influence plant species coexistence and community composition (Kahmen et al. 2006). Evidence from a variety of ecosystems indicates that N-partitioning through preferential uptake of particular $\mathrm{N}$ forms is not uncommon. Early and late successional tree species have been found to display differential uptake of $\mathrm{NO}_{3}^{-}$versus $\mathrm{NH}_{4}^{+}$, respectively, which, due to variation in the availability of these $\mathrm{N}$-forms along successional gradients, affects tree distributions (Stewart et al. 1988; Kronzucker et al. 1997; Aidar et al. 2003). In N-limited arctic and alpine tundra plant communities, species composition was found to correlate with the partitioning of differentially available forms of $\mathrm{N}$, with dominance being linked to a species' ability to exploit the most abundant $\mathrm{N}$-form (McKane et al. 2002; Ashton et al. 2010). Preference for different $\mathrm{N}$-forms has not, however, always been linked to plant species' distributions (e.g., Aanderud and Bledsoe 2009; von Felten et al. 2009). Although the distributions of understory palm species along a soil gradient in a Panamanian tropical forest were more closely linked to nutrient availability than to either rainfall or light (Andersen et al. 2012), no species showed a significant preference for forms of $\mathrm{N}$ that were most abundant in the soils in which they grew. Instead, species' distributions were related to total N-uptake rates (Andersen and Turner 2013).

Flexibility in the use of different $\mathrm{N}$ forms has also been demonstrated in a range of ecosystems. In alpine tundra, some plant species have been found to absorb all $\mathrm{N}$ forms supplied, but alter uptake of them depending on the intensity of competition for $\mathrm{N}$ and the identity of neighboring plants (Miller and Bowman 2002; Miller et al. 2007). Similarly, based on ${ }^{15} \mathrm{~N}$ natural abundance in vegetation and soils, tree species in Hawaiian tropical forests along a rainfall gradient did not appear to specialize on different soil $\mathrm{N}$ pools, but rather responded to changes in the availability of soil $\mathrm{N}$ to exploit the most abundant $\mathrm{N}$-form (Houlton et al. 2007).

The capacity of plants to take up different $\mathrm{N}$ forms should be adaptive, assuming that costs of such plasticity are not high (Scheiner and Berrigan 1998). However, if specialization on particular forms enables dramatically more efficient uptake, then betweenspecies differences in $\mathrm{N}$ uptake strategies may lead to niche partitioning across edaphic gradients varying in supply rates of $\mathrm{N}$ forms, which would facilitate species coexistence (Tilman 1982). Work to date testing this hypothesis in tropical forests has focused on relating tree species' traits (e.g., foliar $\mathrm{N}$ and $\delta^{15} \mathrm{~N}$, nitrate reductase activity) to the availability and isotopic signature of different $\mathrm{N}$-forms (Aidar et al. 2003; Schimann et al. 2008; Andersen et al. 2012) and rates of microbial transformations of $\mathrm{N}$ in soil (Schimann et al. 2008; Andersen et al. 2012). Few studies have directly quantified differences among tropical tree species in the capacity to take up different forms of $\mathrm{N}$, with the exception of Andersen and Turner (2013), who limited their work to understory palms. We sought to fill this gap by testing whether tree species in a Bornean rain forest display differential uptake of different chemical forms of $\mathrm{N}$ using both ${ }^{15} \mathrm{~N}$ natural abundance $\left(\delta^{15} \mathrm{~N}\right)$ and a ${ }^{15} \mathrm{~N}$ tracer experiment. In this forest, most tree species' distributions are tightly correlated with soil resources, causing forest composition to vary dramatically between soil types along an edaphic gradient, resulting in high $\beta$ diversity (Davies et al. 2005) that contributes to the exceptionally high 
species richness of this region (Ashton and Hall 1992). We focused on the two soil types at the extremes of the edaphic gradient, clay and sandy loam (Baillie et al. 2006). These soils share the same climate, due to their close proximity, but differ in supply rates of $\mathrm{N}$-forms, with greater supplies of $\mathrm{NO}_{3}^{-}$than $\mathrm{NH}_{4}^{+}$in clay and greater supplies of $\mathrm{NH}_{4}^{+}$than $\mathrm{NO}_{3}^{-}$in sandy loam (Kochsiek et al. 2013).

twWe hypothesized that edaphic specialization in this Bornean forest may arise due to variation among tree species' in the capacity to take up different chemical forms of $\mathrm{N}$ that are differentially available along the soil gradient. To the extent that differential uptake of $\mathrm{N}$ forms is a proxy for variation between species in resource use ratios (i.e., resource consumption vectors sensu Tilman (1982)), then differences between species in $\mathrm{N}$-form uptake may be a mechanism promoting high $\beta$ diversity. To test this hypothesis, we used foliar $\delta^{15} \mathrm{~N}$ as a first step towards identifying whether trees on sandy loam and clay access different $\mathrm{N}$-forms. We also related foliar $\delta^{15} \mathrm{~N}$ to $\mathrm{C}, \mathrm{N}$, and $\mathrm{P}$ concentrations to help evaluate the growth demand for $\mathrm{N}$ of trees on the two soil types, which affects foliar $\delta^{15} \mathrm{~N}$. Second, we conducted a stable isotope tracer experiment with ${ }^{15} \mathrm{~N}$-labelled ammonium and nitrate using seedlings of nine species with contrasting soil associations in the Dipterocarpaceae, the dominant angiosperm family in this forest. We expected sandy loam specialists to exhibit a greater capacity to absorb $\mathrm{NH}_{4}^{+}$, relative to clay specialists, and clay specialists to exhibit greater capacity to absorb $\mathrm{NO}_{3}^{-}$, relative to sandy loam specialists, reflecting the availability of these $\mathrm{N}$ forms in each soil type. Generalist tree species were expected to exhibit no difference in their capacity to take up either $\mathrm{NO}_{3}^{-}$or $\mathrm{NH}_{4}^{+}$.

\section{Methods}

Study site and supply rates of $\mathrm{N}$-forms

Lambir Hills National Park $\left(4^{\circ} 11^{\prime} \mathrm{N}, 114^{\circ} 01^{\prime} \mathrm{E}\right)$ in Sarawak, Malaysian Borneo, consists of 6,952 ha of lowland mixed dipterocarp rainforest, has the highest tree species richness recorded in the Paleotropics (Ashton and Hall 1992), and is dominated by trees in the Dipterocarpaceae (Lee et al. 2002b). Lambir receives $3,000 \mathrm{~mm}$ of rainfall per year, with $>100 \mathrm{~mm}$ in all

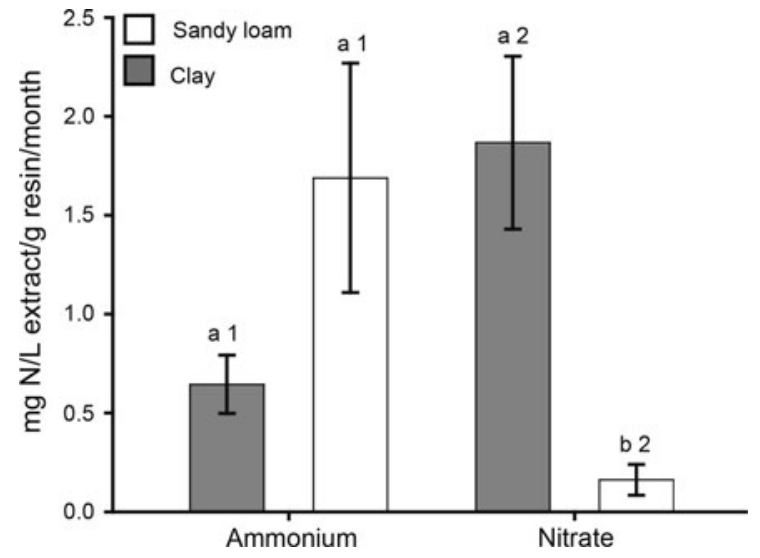

Fig. 1 Differences in ion-exchangeable ammonium $\left(\mathrm{NH}_{4}^{+}\right)$and nitrate $\left(\mathrm{NO}_{3}^{-}\right)$supply rates $(\mathrm{mg} / \mathrm{L}$ extractant/g resin/mo) between clay and sandy loam surface soils underlying Bornean rainforest. Error bars are one standard error; letters indicate significant differences between soil types in the supply rate of each $\mathrm{N}$-form, and numbers indicate significant differences between $\mathrm{N}$-forms in their supply on each soil type $(P<0.05)$. Data are from Kochsiek et al. (2013)

months (Watson 1985), and is the site of a 52-ha longterm research plot (Lee et al. 2002a). All trees $\geq 1 \mathrm{~cm}$ in diameter at breast height (DBH) have been identified to species and are censused ca. every 5 year for survival and DBH.

Soil types within the 52-ha plot experience the same rainfall regime and are sandstone or shalederived. Sandstone-derived soils are humult utisols or sandy haplic acrisols with substantial surficial raw humus and root mat and relatively low nutrient and water retention. Shale-derived soils are clay-rich ultisols generally lacking a humus layer and root mat and have greater nutrient and moisture retention (Baillie et al. 2006). Four soil types have been described based on differences in soil chemistry $(\mathrm{C}$, $\mathrm{N}$ and $\mathrm{P}$ and exchangeable $\mathrm{K}, \mathrm{Ca}$ and $\mathrm{Mg}$ ) and elevation (Davies et al. 2005). Davies et al. (2005) found that of the abundant species at Lambir, $73 \%$ had distributions significantly aggregated on at least one of the four soil types. Here we focus on two soil types, clay and sandy loam, at the extremes of this gradient that differ most in soil properties (Baillie et al. 2006). Supply rates of $\mathrm{NH}_{4}^{+}$and $\mathrm{NO}_{3}^{-}$in surface soil (top $10 \mathrm{~cm}$ ) of clay and sandy loam were quantified in the 52-ha plot over a 5-week period using anion and cation exchange resins as part of a separate study (Kochsiek et al. 2013). Supply rates were expressed as 
nutrient concentration in the solution per dry mass of resin per month burial time. Differences between soil types in supply rates were tested using a linear mixedeffects model with a random effect for location. Clay soil provided significantly greater supply rates of $\mathrm{NO}_{3}^{-}$ and total inorganic $\mathrm{N}$ than sandy loam, but the supply rate of $\mathrm{NH}_{4}^{+}$in sandy loam was not significantly greater than that in clay (Fig. 1). Within soils, the supply rate of $\mathrm{NO}_{3}^{-}$was significantly greater than $\mathrm{NH}_{4}^{+}$ in clay, whereas the supply rate of $\mathrm{NH}_{4}^{+}$was significantly greater than $\mathrm{NO}_{3}^{-}$in sandy loam.

Foliar ${ }^{15} \mathrm{~N}$ natural abundance

Foliar $\delta^{15} \mathrm{~N}$ is viewed as an integrator of terrestrial $\mathrm{N}$-cycling and is known to vary systematically with $\mathrm{N}$-availability to plants, differential $\mathrm{N}$-form use, and relative limitation by $\mathrm{N}$ versus other nutrients (Robinson 2001; Craine et al. 2009; Evans 2001). As part of a survey data collection effort to quantify soil-related variation in leaf functional traits, foliar ${ }^{15} \mathrm{~N}$ natural abundance $\left(\delta^{15} \mathrm{~N}\right)$ was measured for 212 tree species $(n=1-7$ trees per species, $n=1-6$ canopy leaves per tree, DBH range $1-126 \mathrm{~cm}$ ) growing on sandy loam $(n=129$ species $)$ or clay ( $n=83$ species). Species were non- $\mathrm{N}_{2}$-fixing Angiosperms (91 genera, 43 families) that are canopy or subcanopy trees. As part of another study examining leaf functional trait variation of soil specialists and generalists (Russo et al. 2010), $\delta^{15} \mathrm{~N}$ was measured for 31 non- $\mathrm{N}_{2}$-fixing tree species at Lambir in 13 genera (11 Angiosperm families; Table 1): 26 species were congeners specializing on either sandy loam or clay soil, and five species (one for each of five of the 13 genera) were generalists that were sampled on both sandy loam and clay. For each species (specialists) or population (generalists), 1-3 recent, fully expanded leaves were collected from 9 to 11 saplings $(1-3 \mathrm{~cm} \mathrm{DBH})$ growing in either clay or sandy loam soils in the 52-ha forest plot. Leaves were dried for $>72 \mathrm{~h}$ at $60{ }^{\circ} \mathrm{C}$, ground to a uniform, fine powder using a ball mill, and packed into tin capsules. Nitrogen isotope ratio $\left({ }^{15} \mathrm{~N} /{ }^{14} \mathrm{~N}\right)$ and total $\mathrm{N}$ and $\mathrm{C}$ were determined at the University of Arkansas Stable Isotope Laboratory using a NC2500 Finnegan elemental analyzer coupled with a DeltaPlus Thermoquest/Finnegan isotope ratio mass spectrometer. Values are expressed as $\delta^{15} \mathrm{~N}=\left[\left(R_{\text {sample }}\right)\right.$
$\left.\left.R_{\text {standard }}\right)-1\right] \times 1,000$ where $R$ is ${ }^{15} \mathrm{~N} /{ }^{14} \mathrm{~N}$. Foliar $\mathrm{P}$ concentrations were determined with a nitric acid digest followed by analysis with inductively coupled plasma emission spectroscopy (ARCOS, SpectroAnalytical) at the University of Arkansas Agricultural Diagnostics Laboratory.

\section{${ }^{15} \mathrm{~N}$ Isotope tracer experiment}

Uptake rates of ammonium and nitrate were quantified for seedlings of nine species (Table 1) using a ${ }^{15} \mathrm{~N}$ tracer experiment. The experimental species were confined to Dipterocarpaceae due to the availability of seed near Lambir during a masting event in 2009. Species comprised four congeneric pairs specializing on either clay or sandy loam soil, two additional sandy loam specialists, and two generalist species. Seeds were planted in polyethylene bags $(5 \times 7$-in size, except $S$. macrophylla, $6 \times 9$-in size) filled with a 2:1 clay:sand potting mixture created by blending native clay soil collected from the forest at Lambir with washed river sand as 2 parts clay: 1 part sand by volume. Thus, seedlings of all species experienced the same soil medium as in a common-garden. Because all polybags of each size were filled with approximately equal volumes of the potting mixture, all seedlings planted in the same sized polybags were exposed to the same ambient nitrogen levels. Seedlings were grown in a shade house, and all received ambient rainfall that was supplemented during dry periods. At the time of the tracer addition, when all seedlings had been established for a least 6 mos, a total of 376 seedlings were randomly treated with $10 \mathrm{~mL}$ of one of three solutions: $\mathrm{K}^{15} \mathrm{NO}_{3}^{-}\left(0.509 \mathrm{mM}{ }^{15} \mathrm{~N} ; 98\right.$ at.\% $\left.{ }^{15} \mathrm{~N}\right)$, ${ }^{15} \mathrm{NH}_{4}^{+} \mathrm{Cl}\left(2.865 \mathrm{mM}{ }^{15} \mathrm{~N} ; 98\right.$ at.\% $\left.{ }^{15} \mathrm{~N}\right)$, or distilled, deionized water (control). For each species, 7-10 individuals received one of the two ${ }^{15} \mathrm{~N}$ treatments, and five seedlings were controls. A syringe with a 10$\mathrm{cm}$ needle was used to inject $2 \mathrm{~mL}$ of solution uniformly through a depth range of $0-7 \mathrm{~cm}$ at each of five injection points per polybag (a total of $10 \mathrm{~mL}$ per polybag). At the time of injection, seedlings' root systems occupied most of the volume of the polybag, so we consider the injections to have supplied the isotope solutions uniformly within the rooting zone. The solutions applied ${ }^{15} \mathrm{~N}$ at rates that were approximately $2 \%\left({ }^{15} \mathrm{NO}_{3}^{-}\right)$and $11 \%\left({ }^{15} \mathrm{NH}_{4}^{+}\right)$of the total available inorganic $\mathrm{N}$ pool in $5 \times 7$-in polybags and 
Table 1 Taxonomy, growth form, and soil specialization pattern of study tree species in Bornean rain forest measured for foliar natural abundance $\delta^{15} \mathrm{~N}$ (31 species) and used in the ${ }^{15} \mathrm{~N}$ tracer experiment ( 9 species)

\begin{tabular}{|c|c|c|c|c|}
\hline Species & Family & Growth form & Soil specialization & Study \\
\hline Anisoptera grossivenia Sloot. & Dipterocarpaceae & Canopy & Generalist & Tracer \\
\hline Aporusa hosei Merr. & Phyllanthaceae & Subcanopy & Sandy loam & $\delta^{15} \mathrm{~N}$ \\
\hline Aporusa sarawakensis A. Schott & Phyllanthaceae & Subcanopy & Clay & $\delta^{15} \mathrm{~N}$ \\
\hline Calophyllum ferrugineum Merr. & Clusiaceae & Canopy/subcanopy & Sandy loam & $\delta^{15} \mathrm{~N}$ \\
\hline Calophyllum gracilipes Merr. & Clusiaceae & Canopy/subcanopy & Clay & $\delta^{15} \mathrm{~N}$ \\
\hline Dacryodes rostrata (B1.)Lam. forma cuspidata (B1.) Lam. & Burseraceae & Canopy/subcanopy & Clay & $\delta^{15} \mathrm{~N}$ \\
\hline Dacryodes expansa (Ridl.) H.J. Lam & Burseraceae & Canopy/subcanopy & Sandy loam & $\delta^{15} \mathrm{~N}$ \\
\hline Diospyros decipiens C.B. Clarke & Ebenaceae & Canopy/subcanopy & Clay & $\delta^{15} \mathrm{~N}$ \\
\hline Diospyros ferruginescens Bakh. & Ebenaceae & Canopy/subcanopy & Sandy loam & $\delta^{15} \mathrm{~N}$ \\
\hline Diospyros pendula Hasselt ex Hassk. & Ebenaceae & Canopy/subcanopy & Generalist & $\delta^{15} \mathrm{~N}$ \\
\hline Dipterocarpus confertus Sloot. & Dipterocarpaceae & Canopy & Generalist & $\delta^{15} \mathrm{~N}$ \\
\hline Dipterocarpus globosus Vesque & Dipterocarpaceae & Canopy & Sandy loam & $\delta^{15} \mathrm{~N}$, tracer \\
\hline Dipterocarpus kunstleri King & Dipterocarpaceae & Canopy/subcanopy & Clay & $\delta^{15} \mathrm{~N}$ \\
\hline Dryobalanops aromatica C.F. Gaertn. & Dipterocarpaceae & Canopy & Sandy loam & $\delta^{15} \mathrm{~N}$, tracer \\
\hline Dryobalanops lanceolata Burck & Dipterocarpaceae & Canopy & Clay & $\delta^{15} \mathrm{~N}$, tracer \\
\hline Knema latericia Elm. & Myristicaceae & Subcanopy & Generalist & $\delta^{15} \mathrm{~N}$ \\
\hline Knema elmeri Merrill & Myristicaceae & Subcanopy & Clay & $\delta^{15} \mathrm{~N}$ \\
\hline Knema galeata J. Sinclair & Myristicaceae & Subcanopy & Sandy loam & $\delta^{15} \mathrm{~N}$ \\
\hline Macaranga lamellata Whitmore & Euphorbiaceae & Subcanopy & Sandy loam & $\delta^{15} \mathrm{~N}$ \\
\hline Macaranga umbrosa S.J.Davies & Euphorbiaceae & Subcanopy & Clay & $\delta^{15} \mathrm{~N}$ \\
\hline Palaquium cryptocariifolium P.Royen & Sapotaceae & Canopy/subcanopy & Sandy loam & $\Delta^{15} \mathrm{~N}$ \\
\hline Palaquium dasyphyllum Pierre ex Dubard & Sapotaceae & Canopy/subcanopy & Clay & $\delta^{15} \mathrm{~N}$ \\
\hline Polyalthia clavigera King & Annonaceae & Canopy/subcanopy & Sandy loam & $\delta^{15} \mathrm{~N}$ \\
\hline Polyalthia sarawakensis Diels & Annonaceae & Subcanopy & Clay & $\delta^{15} \mathrm{~N}$ \\
\hline Polyalthia rumphii (B1.) Merrill & Annonaceae & Subcanopy & Generalist & $\delta^{15} \mathrm{~N}$ \\
\hline Rinorea bengalensis (Wall.) Kuntze & Violaceae & Subcanopy & Clay & $\delta^{15} \mathrm{~N}$ \\
\hline Rinorea lanceolata Kuntze & Violaceae & Subcanopy & Sandy loam & $\delta^{15} \mathrm{~N}$ \\
\hline Shorea beccariana Burck & Dipterocarpaceae & Canopy & Sandy loam & Tracer \\
\hline Shorea inappendiculata Burck & Dipterocarpaceae & Canopy & Clay & $\delta^{15} \mathrm{~N}$ \\
\hline Shorea laxa Slooten & Dipterocarpaceae & Canopy & Sandy loam & $\delta^{15} \mathrm{~N}$, tracer \\
\hline Shorea patoiensis Ashton & Dipterocarpaceae & Canopy & Generalist & $\delta^{15} \mathrm{~N}$ \\
\hline Shorea macrophylla de Vries (Ashton) & Dipterocarpaceae & Canopy & Clay & Tracer \\
\hline Shorea xanthophylla Sym. & Dipterocarpaceae & Canopy & Clay & Tracer \\
\hline Syzygium cf. grande (Wight) Walp. & Myrtaceae & Canopy/subcanopy & Sandy loam & $\delta^{15} \mathrm{~N}$ \\
\hline Syzygium kingii (Merr.) Merr. and L.M.Perry & Myrtaceae & Canopy/subcanopy & Clay & $\delta^{15} \mathrm{~N}$ \\
\hline Vatica nitens King & Dipterocarpaceae & Canopy/subcanopy & Sandy loam & Tracer \\
\hline
\end{tabular}

None of the study species fixes $\mathrm{N}_{2}$

$1 \%\left({ }^{15} \mathrm{NO}_{3}^{-}\right)$and $7 \%\left({ }^{15} \mathrm{NH}_{4}^{+}\right)$in $6 \times 9$-in polybags, as our goal was to produce a ${ }^{15} \mathrm{~N}$-tracer signal without inducing a fertilization effect. Our calculations are based on $\mathrm{NH}_{4}^{+}$and $\mathrm{NO}_{3}^{-}$concentrations from $1 \mathrm{M} \mathrm{KCl}$ extracts of the clay soil (S.E. Russo, unpub. data), adjusted for volume in the potting mixture, and a bulk density of $1.23 \mathrm{~g} / \mathrm{cm}^{3}$ for the mixture. We calculated dilution of the ${ }^{15} \mathrm{~N}$ tracer in each $\mathrm{N}$ pool $\left(\mathrm{NH}_{4}^{+}, \mathrm{NO}_{3}^{-}\right)$ using the same set of soil values (see "Calculations and statistical analysis" section).

One leaf per plant was harvested at $24 \mathrm{~h}$ as a check on ${ }^{15} \mathrm{~N}$ recovery. Seedlings were harvested in their 
entirety $48 \mathrm{~h}$ following ${ }^{15} \mathrm{~N}$ tracer addition and separated into below- and aboveground tissue and dried at $60{ }^{\circ} \mathrm{C}$ for 2 weeks. Dried leaf samples were weighed and ground to a uniform, fine powder using a ball mill. A mass of 4-5 mg of each ground sample was packed in tin capsules for ${ }^{15} \mathrm{~N}$ and total $\mathrm{N}$ analysis at the University of California-Davis, with a PDZ Europa ANCA-GSL elemental analyzer coupled with a PDZ Europa 20-20 isotope ratio mass spectrometer (Sercon Ltd., Cheshire, UK).

\section{Species growth rates}

Growth rates were estimated for the nine study species included in the ${ }^{15} \mathrm{~N}$ tracer experiment using census data from the 52-ha plot at Lambir. Mean stem diameter growth rate $(\mathrm{cm} /$ year) for each species was estimated based on the change in DBH between 1992 and 2003 for trees $1-3 \mathrm{~cm}$ in diameter, divided by the time period in fractional years between censuses.

\section{Calculations and statistical analysis}

We used ${ }^{15} \mathrm{~N}$ recovery in shoots to examine species' capacities for $\mathrm{NH}_{4}^{+}$and $\mathrm{NO}_{3}^{-}$uptake, as in previous studies (e.g., McKane et al. 2002; Miller and Bowman 2002). Only leaves harvested at 48 h (e.g., Andersen and Turner 2013) were used in our analysis due to the low ${ }^{15} \mathrm{~N}$ recovery in leaves harvested at $24 \mathrm{~h}$. Although microbial transformation of the added $\mathrm{N}$ forms could have occurred within the $48 \mathrm{~h}$ incubation period, we interpret our ${ }^{15} \mathrm{~N}$ uptake results as an estimate of the capacity of plants to take up $\mathrm{N}$ from $\mathrm{NH}_{4}^{+}$to $\mathrm{NO}_{3}^{-}$sources, and not as an indication of preference for those forms, per se. Uptake of the ${ }^{15} \mathrm{~N}$ labeled solutions was estimated from the following formula, which calculates $F$, the mass $(\mu \mathrm{g})$ of ${ }^{15} \mathrm{~N}$ that was derived from the tracer for each analyzed sample (i.e., used in the isotopic analysis): $F=(N \times(A-$ $C)$ ) $/ 98$, where $N$ is the total $\mathrm{N}$ in the analyzed sample, $A={ }^{15} \mathrm{~N}$ at. $\%$ in the sample minus the natural abundance of ${ }^{15} \mathrm{~N}(0.3663 \%), C$ is the average ${ }^{15} \mathrm{~N}$ at.\% in the control samples minus 0.3663 , and 98 represents the at.\% of the added isotope (Hauck and Bremner 1976). Uptake rate of ${ }^{15} \mathrm{~N}, U_{L}\left(\mu \mathrm{g}{ }^{15} \mathrm{~N} / \mathrm{g}\right.$ dry leaf tissue/h), was calculated as $(F /(M \times T))$, where $F$ is as above, $M$ is the dry mass ( $\mathrm{g}$ ) of the analyzed sample, and $T$ is number of hours of incubation before harvesting the leaves $(48 \mathrm{~h})$. Uptake rates were also calculated per unit tissue $\mathrm{N}$, to account for interspecific differences in foliar $\mathrm{N}$, in which case $M$ would be mass of $\mathrm{N}(\mathrm{mg})$ in the analyzed sample.

We accounted for dilution of the ${ }^{15} \mathrm{~N}$ tracer using a mixing model in which the uptake of the unlabeled $\mathrm{N}$ form corresponding to the treatment ${ }^{15} \mathrm{~N}$ label $\left(U_{U}\right)$ was estimated as $U_{L} \times\left(m_{U} / m_{L}\right)$, where $m_{L}$ is the mass of ${ }^{15} \mathrm{~N}$-labelled nitrogen injected per treatment, and $m_{U}$ is the mass of the available $\mathrm{N}$-form corresponding to the treatment estimated to be within the rooting zone, and $U_{L}$ is the uptake rate from the labeled $\mathrm{N}$ form $\left(m_{L}\right)$, and $U_{U}$ is uptake from the source $m_{U}$ (McKane et al. 2002). Based on these calculations, we estimate that approximately $7 \%$ of the ambient $\mathrm{NO}_{3}^{-}$ pool and $15 \%$ of the $\mathrm{NH}_{4}^{+}$pool were labeled in the $5 \times 7$-in polybags, and $5 \%\left(\mathrm{NO}_{3}^{-}\right)$and $9 \%\left(\mathrm{NH}_{4}^{+}\right)$of the target $\mathrm{N}$ pools were labeled in the $6 \times 9$-in bags. Uptake of total inorganic $\mathrm{N}$ was estimated as the sum of the uptake rates for $\mathrm{NH}_{4}^{+}$and $\mathrm{NO}_{3}^{-}$.

Statistical analyses were done in $\mathrm{R}$ statistical software (R Core Development Team 2011). Differences in foliar $\delta^{15} \mathrm{~N}$ signatures between trees growing on sandy loam versus clay (survey data) were tested based on species' mean values using a Student's $t$ test. Differences in foliar $\delta^{15} \mathrm{~N}$ signatures between soil specialists in each genus and between populations of generalists growing on each soil type were analyzed using separate linear models for specialists and generalists in R. For specialists, soil specialization (clay or sandy loam) was nested within genus, as specialists were only sampled on their home soil type, with genus as a fixed effect. For generalists, the model structure was similar, except that the population (clay or sandy loam) was nested within species, with species as a fixed effect. For the survey data, species' mean foliar $\delta^{15} \mathrm{~N}$ values were correlated with foliar $\mathrm{N}, \mathrm{P}$, $\mathrm{C}: \mathrm{N}$, and $\mathrm{N}: \mathrm{P}$ using Spearman rank correlation tests. Differences in uptake rates for each $\mathrm{N}$ - form $\left(\mathrm{NH}_{4}^{+}\right.$vs. $\mathrm{NO}_{3}^{-}$) were analyzed using separate generalized least squares linear models for each species. Treatment group was a fixed factor, total seedling dry mass was a covariate (to account for any influence of seedling size on N-uptake), and the variance of the error distribution (Gaussian) was fit for each group due to heteroscedasticity (gls function in R; Pinheiro and Bates 2000). Resource use ratios (sensu Tilman 1982) of specialists were estimated as ratio of species' mean uptake rates 
of $\mathrm{NH}_{4}^{+}$and $\mathrm{NO}_{3}^{-}$. The difference between clay and sandy loam specialists in resource use ratio was tested using a Student's $t$ test. Species' mean uptake rates were correlated with mean foliar $\mathrm{N}$ concentrations and mean diameter growth rates from the 52-ha plot using Spearman rank correlation tests.

\section{Results}

Foliar $\delta^{15} \mathrm{~N}$ signatures were significantly more negative (depleted) in trees growing on sandy loam compared to clay $(t=5.812, d f=196, P<0.001$; Fig. 2). Foliar $\delta^{15} \mathrm{~N}$ signatures also varied significantly between specialists of sandy loam and clay and between populations of generalists on each soil type. In 12 of 13 congeneric comparisons, saplings of sandy loam specialists had significantly more depleted foliar $\delta^{15} \mathrm{~N}$, compared to clay specialists in the same genus (Fig. 3). A similar pattern was seen in four out of five comparisons of generalist species' populations on sandy loam and clay (Fig. 3). Across species, foliar $\delta^{15} \mathrm{~N}$ correlated negatively with foliar C:N $(r=$ $-0.25, S=1,198,289, P<0.001, n=179)$ and $\mathrm{N}: \mathrm{P}$ $(r=-0.20, \quad S=1,167,715, \quad P=0.007, \quad n=180)$ and positively with foliar N $(r=0.30, S=684,314$, $P<0.001, n=180)$ and $\mathrm{P}(r=0.35, S=634,990$, $P<0.001, n=180)$ concentrations.

All species used both inorganic forms of $\mathrm{N}$, but contrary to expectations, sandy loam and clay specialists did not show differential uptake of either chemical form of N (Table 2; Fig. 4). Sandy loam specialists did not show significantly greater uptake of $\mathrm{NH}_{4}^{+}$over $\mathrm{NO}_{3}^{-}$, nor did clay specialists exhibit greater uptake of $\mathrm{NO}_{3}^{-}$over $\mathrm{NH}_{4}^{+}$(Fig. 4). As with the specialists, the one generalist that we tested did not exhibit a significant difference in its capacity to take up $\mathrm{NH}_{4}^{+}$or $\mathrm{NO}_{3}^{-}$(Fig. 4). Our estimates of uptake rate calculated per unit mass of $\mathrm{N}$ in leaf tissue showed the same patterns as those calculated per unit leaf dry mass (Table 2). Sandy loam and clay specialists did not differ significantly in their mean resource use ratios $(t=-0.827, d f=5.9, P=0.441)$. Across species stem diameter growth rates were not correlated with the uptake rate of either $\mathrm{N}$ form across species $\left(\mathrm{NH}_{4}^{+}\right.$: $r=-0.48, S=178, P=0.194 ; \mathrm{NO}_{3}^{-}: r=-0.55$, $S=186, P=0.133 ; n=9)$, nor with total inorganic N-uptake ( $r=-0.43, S=172, P=0.250, n=9)$.

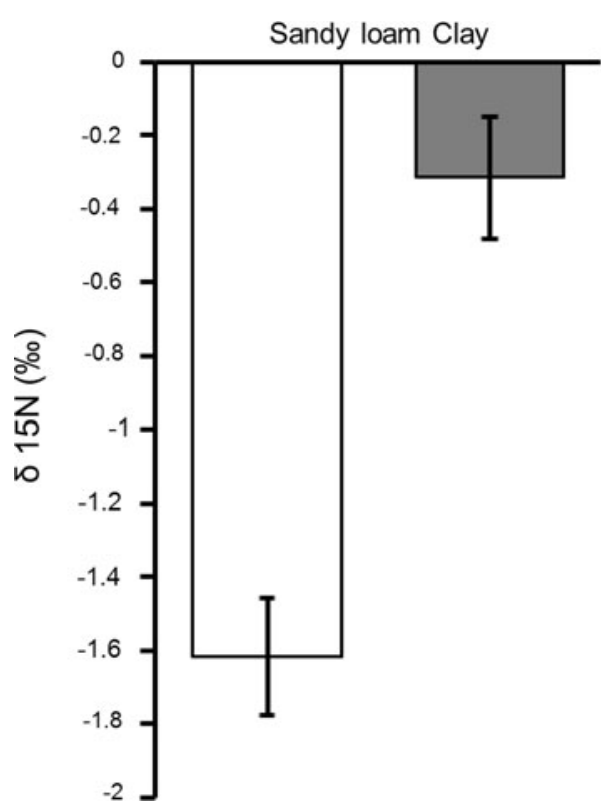

Fig. 2 Variation in community-level foliar $\delta^{15} \mathrm{~N}(\%)$ of Bornean tree species growing on sandy loam (129 species; white) or clay ( 83 species; gray). Error bars are \pm 1 SE. The difference in $\delta^{15} \mathrm{~N}$ between soil types was significant $(P<0.001)$

However, foliar $\mathrm{N}$ concentration was positively correlated with total inorganic $\mathrm{N}$-uptake rate across species $(r=0.68, S=38, P=0.050, n=9)$. The greatest differences among species were in total inorganic N-uptake rate, with Vatica micrantha (sandy loam specialist) and Anisoptera grossivenia (generalist) showing the fastest rates.

\section{Discussion}

Despite variation in the supply rates of ammonium and nitrate in the clay and sandy loam soils underlying this Bornean rain forest and the nearly $4 \%$ difference in foliar $\delta^{15} \mathrm{~N}$ between most soil specialists and populations of generalists, the results of our ${ }^{15} \mathrm{~N}$ tracer experiment showed little support for the hypothesis that tree species associated with these soils vary consistently in their use of different inorganic $\mathrm{N}$ forms or in the ratio in which these forms are used. Instead of distinct strategies of $\mathrm{N}$-form use, our results support the idea that these tree species have evolved similar, flexible capacities to take up different forms of inorganic N. Few studies have experimentally tested 
Fig. 3 Variation in foliar $\delta^{15} \mathrm{~N}(\%)$ of 31 Bornean tree species in 13 genera: pairwise comparisons of congeneric soil specialist species and soil generalist populations on sandy loam (white) or clay (gray) soil. Error bars are $\pm 1 \mathrm{SE}$; asterisks indicate genera (or species) with significant differences $(P<0.05)$ between soils based on posthoc comparisons following a signficant effect of genus (specialists) or species (generalists) in linear models. Study species are listed in Table 1

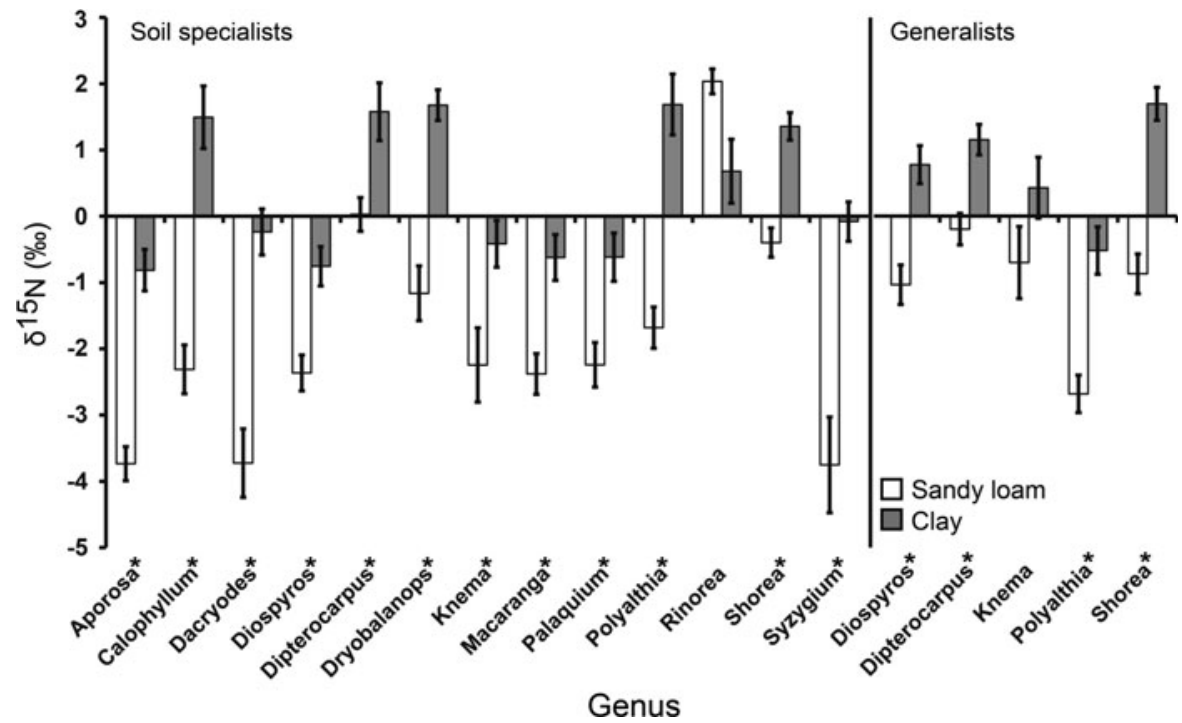

Table 2 Analysis of variance tables for each Bornean dipterocarp species showing the effect of $\mathrm{N}$-form treatment on rates of nitrogen uptake, calculated per unit leaf dry mass (dry mass basis; $\mu \mathrm{g}{ }^{15} \mathrm{~N} / \mathrm{g}$ dry leaf tissue/h) and per unit total $\mathrm{N}$ in leaf tissue (total $\mathrm{N}$ basis; $\mu \mathrm{g}{ }^{15} \mathrm{~N} / \mathrm{mgN}$ in leaf tissue/h)

\begin{tabular}{|c|c|c|c|c|c|}
\hline & \multirow[t]{2}{*}{$\begin{array}{l}N_{d f} \\
D_{d f}\end{array}$} & \multicolumn{2}{|c|}{$\begin{array}{l}\text { Dry mass } \\
\text { basis }\end{array}$} & \multicolumn{2}{|c|}{ Leaf $\mathrm{N}$ basis } \\
\hline & & $F$ & $P$ & $F$ & $P$ \\
\hline \multicolumn{6}{|l|}{ Sandy loam specialists } \\
\hline $\begin{array}{l}\text { Dipterocarpus } \\
\text { globosus }\end{array}$ & 1,14 & 0.663 & 0.429 & 0.769 & 0.395 \\
\hline $\begin{array}{c}\text { Dryobalanops } \\
\text { aromatica }\end{array}$ & 1,17 & 0.565 & 0.463 & 0.555 & 0.467 \\
\hline Shorea beccariana & 1,16 & 0.001 & 0.981 & 0.011 & 0.919 \\
\hline Shorea laxa & 1,10 & 0.138 & 0.718 & 0.031 & 0.865 \\
\hline $\begin{array}{l}\text { Vatica nitens } \\
\text { Clay specialists }\end{array}$ & 1,13 & 1.551 & 0.235 & 1.857 & 0.196 \\
\hline $\begin{array}{l}\text { Dryobalanops } \\
\text { lanceolata }\end{array}$ & 1,17 & 0.634 & 0.437 & 0.252 & 0.622 \\
\hline Shorea macrophylla & 1,15 & 0.685 & 0.421 & 0.803 & 0.384 \\
\hline $\begin{array}{l}\text { Shorea xanthophylla } \\
\text { Generalist }\end{array}$ & 1,13 & 0.014 & 0.908 & 0.053 & 0.822 \\
\hline $\begin{array}{l}\text { Anisoptera } \\
\text { grossivenia }\end{array}$ & 1,17 & 0.901 & 0.356 & 0.746 & 0.400 \\
\hline
\end{tabular}

The numerator and denominator degrees of freedom $\left(N_{d f}, D_{d f}\right)$, $F$-statistic $(F)$, and probability $(P)$ of each test are listed

for differential $\mathrm{N}$-form use among tropical plants. Our findings are consistent with a small but growing body evidence demonstrating flexible $\mathrm{N}$-use among tropical plants, including a ${ }^{15} \mathrm{~N}$ tracer experiment in

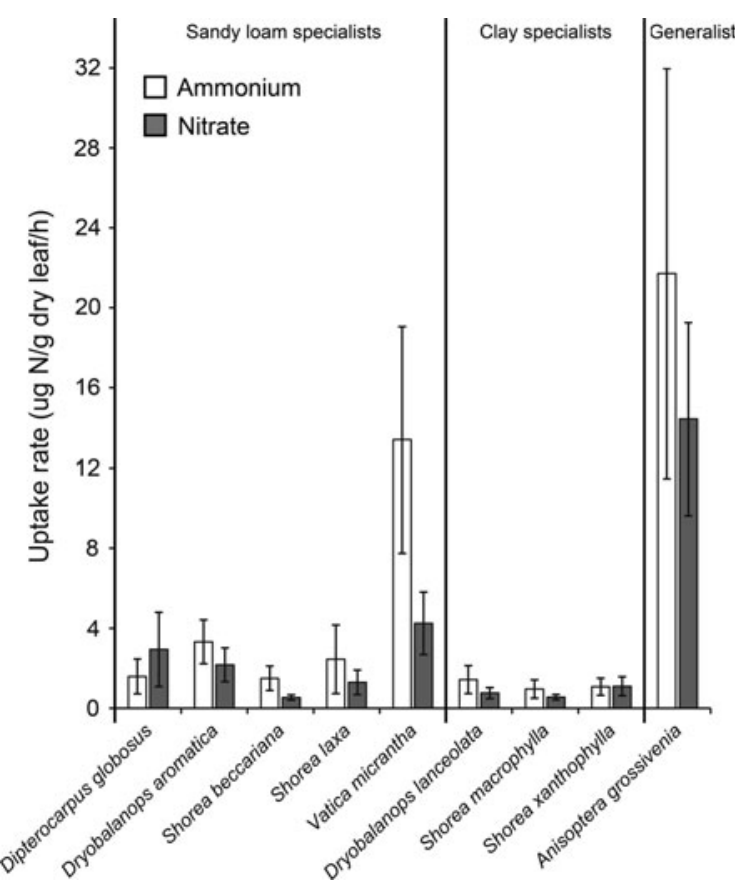

Fig. 4 Differences in relative uptake rates of ammonium $\left(\mathrm{NH}_{4}^{+}\right)$and nitrate $\left(\mathrm{NO}_{3}^{-}\right)$for nine Bornean tree species that specialize on sandy loam or clay soil types (specialists) or show no soil association (generalist). Error bars are \pm 1 SE; there were no statistically significant differences in uptake rates of the two $\mathrm{N}$ forms for any species (Table 2)

Panamanian forest that also found limited evidence for $\mathrm{N}$-form preferences of understory palm species distributed on different soil types (Andersen and Turner 2013) and studies suggesting flexibility in 
$\mathrm{N}$-form use by Hawaiian plant species (Houlton et al. 2007) and Jamaican tree species (Brearley 2013). Plasticity in the use of different $\mathrm{N}$ forms may be adaptive if it allows for more effective competition for $\mathrm{N}$ resources at the root-level, where availability of different forms can fluctuate on small spatial and temporal scales due to variation in, e.g., mineralization rates, soil moisture, and differential diffusion (Nye 1977; Owen and Jones 2001; Miller and Cramer 2004), as well as competition with neighboring plants and microorganisms (Schimel and Bennett 2004; Harrison et al. 2007; Miller et al. 2007). Variation among tree species in the capacity to take up differentially available inorganic $\mathrm{N}$ forms is thus unlikely to be a dominant mechanism influencing their distributions across soil types in this Bornean rain forest. However, our foliar $\delta^{15} \mathrm{~N}$ results nevertheless showed significant soil-related variation, suggesting that trees on the two soil types have access to $\mathrm{N}$ with different $\delta^{15} \mathrm{~N}$.

Nitrogen use strategies inferred from ${ }^{15} \mathrm{~N}$ natural abundance

Uptake of $\mathrm{N}$ by plants is not considered to cause appreciable isotopic fractionation (Hogberg 1997; Dawson et al. 2002), and fractionation associated with translocation within the plant is considered minimal (Dawson et al. 2002), so foliar $\delta^{15} \mathrm{~N}$ is often assumed to be similar to the $\delta^{15} \mathrm{~N}$ of the $\mathrm{N}$ source used by plants (Houlton et al. 2007). The depleted foliar $\delta^{15} \mathrm{~N}$ values among Bornean trees growing on sandy loam and their negative relationships with foliar $\mathrm{C}: \mathrm{N}$ suggest decreased $\mathrm{N}$-availability to plants on sandy loam compared to clay (Craine et al. 2009). In all but one congeneric comparison (Rinorea), foliar $\delta^{15} \mathrm{~N}$ values were also significantly depleted in sandy loam, compared to clay, specialists, as well as in populations of generalists growing on sandy loam compared to clay. There is no obvious explanation as to why Rinorea differed from the other genera. However, there are at least three plausible explanations for the otherwise dominant patterns: (1) these tree species are not using a common source of $\mathrm{N}$ across soil types; (2) they are using a common source of $\mathrm{N}$, but the $\delta^{15} \mathrm{~N}$ of that source varies between soil types; or (3) both factors may be contributing to the observed differences in foliar $\delta^{15} \mathrm{~N}$. Although we cannot definitively distinguish between these alternatives with our data, the tracer experiment revealed little evidence of differential uptake of inorganic $\mathrm{N}$ for any species. Our findings are thus consistent with the hypothesis that these species may be able to use whichever inorganic $\mathrm{N}$-form is in greatest supply and that the $\delta^{15} \mathrm{~N}$ of the $\mathrm{N}$ form(s) accessed by trees on sandy loam and clay likely differs.

Differences in $\delta^{15} \mathrm{~N}$ in bulk soils along gradients are influenced by $\mathrm{N}$-isotope fractionation associated with microbial processes, including nitrification and denitrification, and with gaseous losses (Hogberg 1997; Robinson 2001; Houlton et al. 2006). These pathways tend to cause enrichment of the remaining soil ${ }^{15} \mathrm{~N}$ pool, leading to enriched foliar $\delta^{15} \mathrm{~N}$. One explanation of our results is that differences between soil types in these fractionating processes could produce variation in the bulk soil $\delta^{15} \mathrm{~N}$, which is then reflected in foliar $\delta^{15} \mathrm{~N}$ signatures of trees on the two soil types. In $\mathrm{N}$ limited systems with tighter $\mathrm{N}$-cycling, pathways for $\mathrm{N}$ loss are reduced, resulting in depleted foliar $\delta^{15} \mathrm{~N}$ (Hogberg 1997). Although total soil $\mathrm{N}$ does not differ between soil types (Baillie et al. 2006), and N may not be a primary limiting nutrient in this forest (Kochsiek et al. 2013), the dominance of $\mathrm{NH}_{4}^{+}$, the welldeveloped, recalcitrant organic layer, and slower litter decomposition rates in sandy loam (Baillie et al. 2006) suggest tighter nutrient cycling, and lower $\mathrm{N}$ availability to plants than in clay, consistent with the depleted foliar $\delta^{15} \mathrm{~N}$ signatures seen in trees growing on this soil type. A survey of foliar $\delta^{15} \mathrm{~N}$ among tropical forests also found more depleted values in forests with low $\mathrm{N}$-availability, such as those on sandier soils (Martinelli et al. 1999). Indeed, our foliar $\delta^{15} \mathrm{~N}$ values from sandy loam are similar to those from an N-limited Brazilian savanna (Bustamante et al. 2004), and three sandy loam specialists had foliar $\delta^{15} \mathrm{~N}$ values as low as those observed in strongly $\mathrm{N}$-limited Hawaiian forests (Vitousek et al. 1989). The soilrelated differences in foliar $\delta^{15} \mathrm{~N}$ we found also paralleled variation between mor and mull soils in Jamaican montane forest. The mor soil, with a thick, acidic humus layer, resembling that on the sandy loam in our site, exhibited relatively depleted foliar and soil $\delta^{15} \mathrm{~N}$, interpreted as evidence of a tighter $\mathrm{N}$-cycle (Brearley 2013). Along a gradient of $\mathrm{N}$-availability in forests on Mount Kinabalu, Borneo, foliar $\delta^{15} \mathrm{~N}$ correlated positively with soil $\mathrm{NO}_{3}^{-}$availability, and 
negatively with $\mathrm{NH}_{4}^{+}$availability, in parallel to our findings, a result the authors attribute to leaching losses of $\mathrm{NO}_{3}^{-}$(Kitayama and Iwamoto 2001).

The dominant family of trees in this forest, Dipterocarpaceae, form ectomycorrhizal associations, although trees forming arbuscular mycorrhizal associations are also present and were represented in our survey data. Mycorrhizal associations are often more common in $\mathrm{N}$ - and P-poor soils and can result in depleted foliar $\delta^{15} \mathrm{~N}$ values relative to bulk soil $\delta^{15} \mathrm{~N}$, with more negative values for ectomycorrhizal than arbuscular mycorrhizal associations (Hogberg 1997; Michelsen et al. 1998; Hobbie and Colpaert 2003; Craine et al. 2009). Hence, another explanation for the soil-related differences in foliar $\delta^{15} \mathrm{~N}$ in this forest is that trees on sandy loam may rely more heavily on mycorrhizal sources of $\mathrm{N}$, relative to trees on clay, a mechanism that can operate independently of soil-typerelated differences in the bulk soil $\delta^{15} \mathrm{~N}$. Furthermore, the magnitude of the soil-related difference in foliar $\delta^{15} \mathrm{~N}$ varied among generalist species, suggesting that foliar $\delta^{15} \mathrm{~N}$ of these species is not a simple function of bulk soil $\delta^{15} \mathrm{~N}$. Instead, differences in competitive interactions among trees and with microorganisms for $\mathrm{N}$ or differences in mycorrhizal associations between soil types may also operate to produce variability in foliar $\delta^{15} \mathrm{~N}$. More detailed comparative data on $\delta^{15} \mathrm{~N}$ of $\mathrm{N}$ forms in soil, microbial $\mathrm{N}$ mineralization rates, $\mathrm{N}$ loss rates, and mycorrhizal infection in sandy loam and clay soil would help to further elucidate the underlying causes of these soil-related differences in foliar $\delta^{15} \mathrm{~N}$.

Lack of nitrogen-form preference: Possible ecological interpretations

We cannot rule out the possibility that plants receiving the ${ }^{15} \mathrm{~N}-\mathrm{NH}_{4}^{+}$tracer took up both forms of $\mathrm{N}\left(\mathrm{NH}_{4}^{+}\right.$and $\mathrm{NO}_{3}^{-}$), since $\mathrm{NH}_{4}^{+}$could have been retained in the clay fraction and subsequently nitrified to $\mathrm{NO}_{3}^{-}$. However, in this study and a similar one by Andersen and Turner (2013), one or more species showed a trend of greater mean uptake of ${ }^{15} \mathrm{~N}-\mathrm{NO}_{3}^{-}$, suggesting that even if $\mathrm{N}$ was better retained in the $\mathrm{NH}_{4}^{+}$treatment, our experiment had the capacity to detect differential use of $\mathrm{N}$-forms.

Many, but not all, studies testing for variation in $\mathrm{N}$ uptake among plant species find evidence of species' preference for different forms of $\mathrm{N}$ (see Introduction).
Those that find evidence of preference are often from markedly N-limited systems, such as arctic, alpine, and $\mathrm{N}$-poor grasslands. One possible explanation for our finding of lack of differential uptake of $\mathrm{N}$-forms is that tree growth in this Bornean forest may not be primarily limited by inorganic N. If so, then selection for adaptations to partition inorganic $\mathrm{N}$ resources between species may be weak. Some evidence points towards this hypothesis. First, a study of in situ standing biomass and growth rates of fine roots at Lambir demonstrated that $\mathrm{PO}_{4}^{-3}$ and $\mathrm{K}^{+}$are likely to limit tree growth (Kochsiek et al. 2013). Nitrate and ammonium supply rates in soil did not correlate strongly with either standing biomass or growth rates of fine roots, signifying that inorganic $\mathrm{N}$ may only be secondarily limiting or that acquisition of $\mathrm{N}$ via mycorrhizal associations may be more important. Second, foliar $\delta^{15} \mathrm{~N}$ was negatively related to $\mathrm{N}: \mathrm{P}$ ratio, consistent with other studies of P-limited systems (McKee et al. 2002; Clarkson et al. 2005; Wanek and Zotz 2011). Although trees may store excess $\mathrm{P}$ in leaves, foliar N:P ratios are considered an indicator of the relative limitation of plant growth by $\mathrm{N}$ versus $\mathrm{P}$ (Güsewell 2004). To the extent that this is true, greater $\mathrm{N}: \mathrm{P}$ ratios should be associated with more depleted foliar $\delta^{15} \mathrm{~N}$, since due to limitation by $\mathrm{P}$, not all bulk soil $\mathrm{N}$ that is available in the system is assimilated, resulting in greater opportunity for discrimination (Evans 2001). Third, studies in N-limited systems often find a significant relationship between plant growth and $\mathrm{N}$-use strategy, with the fastest growing, dominant species often exhibiting preference for the most abundant $\mathrm{N}$ form (McKane et al. 2002; Ashton et al. 2010; Scott and Rothstein 2011). Although foliar $\mathrm{N}$ concentration correlated with $\mathrm{N}$-uptake rates of seedlings across species, we found no correlation between uptake and diameter growth rates of saplings, which would be expected if $\mathrm{N}$ resource partitioning between species was a strong determinant of carbon acquisition and growth.

\section{Conclusions}

Differential use of inorganic $\mathrm{N}$ forms does not appear to be an overriding mechanism producing the observed soil-specific distributions of tree species and high $\beta$ diversity across the edaphic gradient in this rainforest. Instead, our results imply that these 
Bornean tree species display considerable flexibility both in the uptake of different inorganic $\mathrm{N}$ forms and, potentially, in reliance on ectomycorrhizal associations for $\mathrm{N}$-supply. That flexibility would facilitate $\mathrm{N}$ acquisition when the availability of $\mathrm{N}$ forms in the rhizosphere varies in space and time and could potentially result in functional redundancy among tree species in their responses to nitrogen gradients and their influence on ecosystem $\mathrm{N}$-cycles.

Acknowledgments The authors thank the Sarawak Forest Department, National Parks, and Forest Research Corporation for their kind permission to conduct research in Lambir Hills National Park. This research was made possible by funds from the US National Science Foundation (NSF) award DEB0919136 to SER, including an NSF-Research Experiences for Undergraduates supplementary award, the Center for Tropical Forest Science, and from the University of Nebraska-Lincoln Undergraduate Creative Activities and Research Experiences Program. The 52-ha plot is a collaborative project of the Center for Tropical Forest Science, Forest Department of Sarawak, Malaysia, Harvard University, USA (NSF awards DEB9107247 and DEB-9629601 to P. S. Ashton), and Osaka City University, Japan (Monbusho grant 06041094 to T. Yamakura, 08NP0901 to S. Tamura and 09NP0901 to S. Sasaki). The authors thank Lela Ali and Aimee Koenig for field assistance, Ramesh Laungani for helpful discussions about stable isotope tracer experiments, and David Wedin for comments on an earlier version of this manuscript.

\section{References}

Aanderud ZT, Bledsoe CS (2009) Preferences for 15n-ammonium, $15 n$-nitrate, and 15n-glycine differ among dominant exotic and subordinate native grasses from a california oak woodland. Environ Exp Bot 65:205-209

Aidar MPM, Schmidt S, Moss G, Stewart GR, Joly CA (2003) Nitrogen use strategies of neotropical rainforest trees in threatened atlantic forest. Plant Cell Environ 26:389-399

Andersen KM, Turner BL (2013) Preferences or plasticity in nitrogen acquisition by understorey palms in a tropical montane forest. J Ecol 101:819-825

Andersen KM, Endara MJ, Turner BL, Dalling JW (2012) Traitbased community assembly of understory palms along a soil nutrient gradient in a lower montane tropical forest. Oecologia 168:519-531

Ashton PS (1964) Ecological studies in the mixed dipterocarp forests of Brunei state. Oxf For Mem 25:1-75

Ashton PS, Hall P (1992) Comparisons of structure among mixed dipterocarp forests of north-western Borneo. J Ecol 80:459-481

Ashton IW, Miller AE, Bowman WD, Suding KN (2010) Niche complementarity due to plasticity in resource use: plant partitioning of chemical $n$ forms. Ecology 91:3252-3260

Baillie IC, Ashton PS, Chin SP, Davies SJ, Palmiotto PA, Russo SE, Tan S (2006) Spatial associations of humus, nutrients, and soils in mixed dipterocarp forest at Lambir, Sarawak, Malaysian Borneo. J Trop Ecol 22:543-553

Brearley FQ (2013) Nitrogen stable isotopes indicate differences in nitrogen cycling between two contrasting Jamaican montane forests. Plant Soil 367:465-476

Bustamante MMC, Martinelli LA, Silva DA, Camargo PB, Klink CA, Domingues TF, Santos RV (2004) 15n natural abundance in woody plants and soils of central Brazilian savannas (cerrado). Ecol Appl 14:S200-S213

Chapin FS, Vitousek PM, Cleve KV (1986) The nature of nutrient limitation in plant communities. Am Nat 127:48-58

Chapin FS, Autumn K, Pugnaire F (1993) Evolution of suites of traits in response to environmental stress. Am Nat 142:S78-S92

Chazdon RL (1986) Light variation and carbon gain in rain forest understorey palms. J Ecol 74:995-1012

Clarkson BR, Schipper LA, Moyersoen B, Silvester WB (2005) Foliar $15 \mathrm{n}$ natural abundance indicates phosphorus limitation of bog species. Oecologia 144:550-557

Craine JM, Elmore AJ, Aidar MPM, Bustamante M, Dawson TE, Hobbie EA, Kahmen A, Mack MC, McLauchlan KK, Michelsen A, Nardoto GB, Pardo LH, Peñuelas J, Reich PB, Schuur EAG, Stock WD, Templer PH, Virginia RA, Welker JM, Wright IJ (2009) Global patterns of foliar nitrogen isotopes and their relationships with climate, mycorrhizal fungi, foliar nutrient concentrations, and nitrogen availability. New Phytol 183:980-992

Dalling JW, Hubbell SP (2002) Seed size, growth rate and gap microsite conditions as determinants of recruitment success for pioneer species. J Ecol 90:557-568

Davies SJ, Tan S, LaFrankie JV, Potts MD (2005) Soil-related floristic variation in the hyperdiverse dipterocarp forest in lambir hills, sarawak. In: Roubik DW, Sakai S, Hamid A (eds) Pollination ecology and rain forest diversity, Sarawak studies. Springer, New York, pp 22-34

Dawson TE, Mambelli S, Plamboeck AH, Templer PH, Tu KP (2002) Stable isotopes in plant ecology. Annu Rev Ecol Syst 33:507-559

Evans RD (2001) Physiological mechanisms influencing plant nitrogen isotope composition. Trends Plant Sci 6:121-126

Field C, Mooney HA (1990) The photosynthesis-nitrogen relationship in wild plants. In: Givnish T (ed) On the economy of plant form and function. Cambridge University Press, Cambridge, pp 25-55

Grime JP (1979) Plant strategies and vegetation processes. Wiley, New York

Güsewell S (2004) N:P ratios in terrestrial plants: variation and functional significance. New Phytol 164:243-266

Harrison KA, Bol R, Bardgett RD (2007) Preferences for uptake of different nitrogen forms by co-existing plant species and soil microbes in temperate grasslands. Ecology 88:989-999

Hauck RD, Bremner JM (1976) Use of tracers for soil and fertilizer nitrogen research. Adv Agron 28:219-260

Hobbie EA, Colpaert JV (2003) Nitrogen availability and colonization by mycorrhizal fungi correlate with nitrogen isotope patterns in plants. New Phytol 157:115-126

Hogberg P (1997) Tansley review no. 95. 15n natural abundance in soil-plant systems. New Phytol 137:179-203

Houlton BZ, Sigman DM, Hedin LO (2006) Isotopic evidence for large gaseous nitrogen losses from tropical rainforests. Proc Natl Acad Sci USA 103:8745-8750 
Houlton BZ, Sigman DM, Schuur EAG, Hedin LO (2007) A climate-driven switch in plant nitrogen acquisition within tropical forest communities. Proc Natl Acad Sci USA 104:8902-8906

Janzen DH (1974) Tropical blackwater rivers, animals, and mast fruiting by the Dipterocarpaceae. Biotropica 6:69-103

Kahmen A, Renker C, Unsicker SB, Buchmann N (2006) Niche complementarity for nitrogen: an explanation for the biodiversity and ecosystem functioning relationship? Ecology $87: 1244-1255$

Kitayama K, Iwamoto K (2001) Patterns of natural 15n abundance in the leaf-to-soil continuum of tropical rain forests differing in $\mathrm{n}$ availability on mount Kinabalu, Borneo. Plant Soil 229:203-212

Kobe RK, Pacala SW, Silander JA, Canham CD (1995) Juvenile tree survivorship as a component of shade tolerance. Ecol Appl 5:517-532

Kochsiek A, Tan S, Russo SE (2013) Fine root dynamics in relation to nutrients in oligotrophic Bornean rain forest soils. Plant Ecol 214:869-882

Kronzucker HJ, Siddiqi MY, Glass ADM (1997) Conifer root discrimination against soil nitrate and the ecology of forest succession. Nature 385:59-61

Lee HS, Ashton PS, Yamakura T, Tan S, Davies SJ, Itoh A, Chai EOK, Ohkubo T, LaFrankie JV (2002a) The 52-ha forest research plot at Lambir Hills National Park, Sarawak, Malaysia: Tree distribution maps, diameter tables, and species documentation. Sarawak Forest Department, Center for Tropical Forest Science-Arnold Arboretum Asia Program, \& Smithsonian Tropical Research Institute, Kuching

Lee HS, Davies SJ, LaFrankie JV, Tan S, Yamakura T, Itoh A, Ohkubo T, Ashton PS (2002b) Floristic and structural diversity of mixed dipterocarp forests in Lambir Hills National Park, Sarawak, Malaysia. J Trop For Sci 14:379-400

Marschner H (1995) Mineral nutrition in higher plants, 2nd edn. Academic, London

Martinelli LA, Piccolo MC, Townsend AR, Vitousek PM, Cuevas E, McDowell W, Robertson GP, Santos OC, Treseder K (1999) Nitrogen stable isotopic composition of leaves and soil: tropical versus temperate forests. Biogeochemistry 46:45-65

McKane RB, Johnson LC, Shaver GR, Nadelhoffer KJ, Rastetteri EB, Fry B, Giblini AE, Kielland K, Kwiatowskii BL, Laundrei JA, Murray G (2002) Resource-based niches provide a basis for plant species diversity and dominance in arctic tundra. Nature 415:68-71

McKee KL, Feller IC, Popp M, Wanek W (2002) Mangrove isotopic $(\delta 15 \mathrm{n}$ and $\delta 13 \mathrm{c})$ fractionation across a nitrogen versus phosphorus limitation gradient. Ecology 83:10651075

Michelsen A, Quarmby C, Sleep D, Jonasson S (1998) Vascular plant $15 \mathrm{n}$ natural abundance in heath and forest tundra ecosystems is closely correlated with presence and type of mycorrhizal fungi in roots. Oecologia 115:406-418

Miller A, Bowman W (2002) Variation in nitrogen-15 natural abundance and nitrogen uptake traits among co-occurring alpine species: do species partition by nitrogen form? Oecologia 130:609-616

Miller AJ, Cramer MD (2004) Root nitrogen acquisition and assimilation. Plant Soil 274:1-36
Miller AE, Bowman WD, Suding KN (2007) Plant uptake of inorganic and organic nitrogen: neighbor identity matters. Ecology 88:1832-1840

Nye PH (1977) The rate-limiting step in plant nutrient absorption from soil. Soil Sci 123:292-297

Owen AG, Jones DL (2001) Competition for amino acids between wheat roots and rhizosphere microorganisms and the role of amino acids in plant $\mathrm{n}$ acquisition. Soil Biol Biochem 33:651-657

Pinheiro JC, Bates DM (2000) Mixed-effects models in s and s-plus. Springer, New York

R Development Core Team (2011) R: A language and environment for statistical computing, v. 2.10.1, R Foundation for Statistical Computing, Vienna, Austria. http://www.Rproject.org

Robinson D (2001) Delta n-15 as an integrator of the nitrogen cycle. Trends Ecol Evol 16:153-162

Russo SE, Cannon WL, Elowsky C, Tan S, Davies SJ (2010) Variation in leaf stomatal traits of 28 tree species in relation to gas exchange along an edaphic gradient in a Bornean rain forest. Am J Bot 97:1109-1120

Scheiner SM, Berrigan D (1998) The genetics of phenotypic plasticity. VIII. The cost of plasticity in daphnia pulex. Evolution 52:368-378

Schimann H, Ponton S, Hättenschwiler S, Ferry B, Lensi R, Domenach A-M, Roggy J-C (2008) Differing nitrogen use strategies of two tropical rainforest late successional tree species in French Guiana: evidence from 15n natural abundance and microbial activities. Soil Biol Biochem 40:487-494

Schimel JP, Bennett J (2004) Nitrogen mineralization: challenges of a changing paradigm. Ecology 85:591-602

Scott E, Rothstein D (2011) Amino acid uptake by temperate tree species characteristic of low- and high-fertility habitats. Oecologia 167:547-557

Stewart GR, Hegarty EE, Specht RL (1988) Inorganic nitrogen assimilation in plants of Australian rainforest communities. Physiol Plant 74:26-33

Tilman D (1982) Resource competition and community structure. Princeton University Press, Princeton

Vitousek PM, Shearer G, Kohl DH (1989) Foliar 15n natural abundance in Hawaiian rainforest: patterns and possible mechanisms. Oecologia 78:383-388

von Felten S, Hector A, Buchmann N, Niklaus PA, Schmid B, Scherer-Lorenzen M (2009) Belowground nitrogen partitioning in experimental grassland plant communities of varying species richness. Ecology 90:1389-1399

von Wirén N, Gazzarrini S, Frommer WB (1997) Regulation of mineral nitrogen uptake in plants. Plant Soil 196:191-199

Wanek W, Zotz G (2011) Are vascular epiphytes nitrogen or phosphorus limited? A study of plant $15 \mathrm{n}$ fractionation and foliar $n$ : $p$ stoichiometry with the tank bromeliad vriesea sanguinolenta. New Phytol 192:462-470

Watson H (1985) Lambir Hills National Park: Resource inventory with management recomendations. National Parks and Wildlife Office, Forest Department, Kuching

Whitmore TC (1978) Gaps in the forest canopy. In: Tomlinson PB, Zimmerman MM (eds) Tropical trees as living systems. Cambridge University Press, Cambridge, pp 639-655

Whittaker RH (1956) Vegetation of the great smoky mountains. Ecol Monogr 26:1-80 